\title{
Independence and Trust
}

\begin{abstract}
The Chapter examines the trust of the general public in the judiciary at the national and EU-level. The starting point is that the correlation between the independence of the judiciary as perceived by the general public and the trust in the judiciary by the same public is very strong: trust in the judiciary equals trust in the independence of the judiciary. Trust in the judiciary is generally higher than that in parliament and government. However, the trust in the judiciary is generally at the same level as that in the public administration. It is likely that the general public associates the public administration with desirable, fair and impartial implementation of public policies, and not so much with (divisive) policy formation. Thus, it is too simple to conclude that the judiciary performs better than the other powers of the state. High trust in the judiciary is fostered by the nature of the tasks. At the EU-level the differentiation of trust between the three branches of government is much smaller than at the national level. Trust in the European Court of Justice (the supreme court of the European Union) is higher than in the national judiciary at low levels of trust at the national level, and smaller at high levels of trust. Still, trust in the ECJ is higher in countries with a highly trusted judiciary than in countries with a less trusted judiciary.
\end{abstract}

Keywords Trust · Judiciary · Public institutions - European Union · European Court of Justice 


\subsection{Connection Between Independence And Trust}

Several international surveys exist about trust in institutions. The European Commission has been organizing public opinion surveys for many years. These surveys among the general public in the member states of the EU record trust in national institutions including the national "justice/legal system" and in EU institutions, including the European Court of Justice (formally, the Court of Justice which as supreme court constitutes together with the General Court the Court of Justice of the European Union). While these surveys have as disadvantages that the definition of the justice/legal system is imprecise, and that the answer categories do not allow much distinctiveness (only three categories), the breadth of the surveys makes them particularly relevant for this study. The judiciary is the most important part of this potentially broader concept, and, for ease of exposition, the 'justice/legal system' will be denoted by the 'judiciary' in the sequel. As discussed in Chapter 2, trust in the judiciary and perceptions of judicial independence by citizens are connected. Applying the Eurobarometer survey on judicial independence and the public opinion survey on trust in the judiciary, the correlation between independence as perceived by citizens and trust by citizens, is 0.95 . See Table 6.1. The correlation between perceived independence by companies, which is more based on direct experience with the courts and rational considerations than the perceptions of citizens, and trust of citizens is also high. As discussed before, it is likely that a positive perception of independence fosters trust in the judiciary, but reverse causality cannot be ruled out: people may trust the judiciary, and therefore believe in and respect its independence. For citizens independence of and trust in the judiciary are connected to such an extent that both are not distinguishable: trust in the judiciary seems to be foremost trust in the independence of the judiciary. Given this connection, it is also of interest for the study of judicial independence to compare the trust in the judiciary with the trust in the other branches of the state. It will be shown that independence and impartiality play a role in the trust of citizens in the other state powers as well. Two levels of institutions will be examined, national and European Union. 


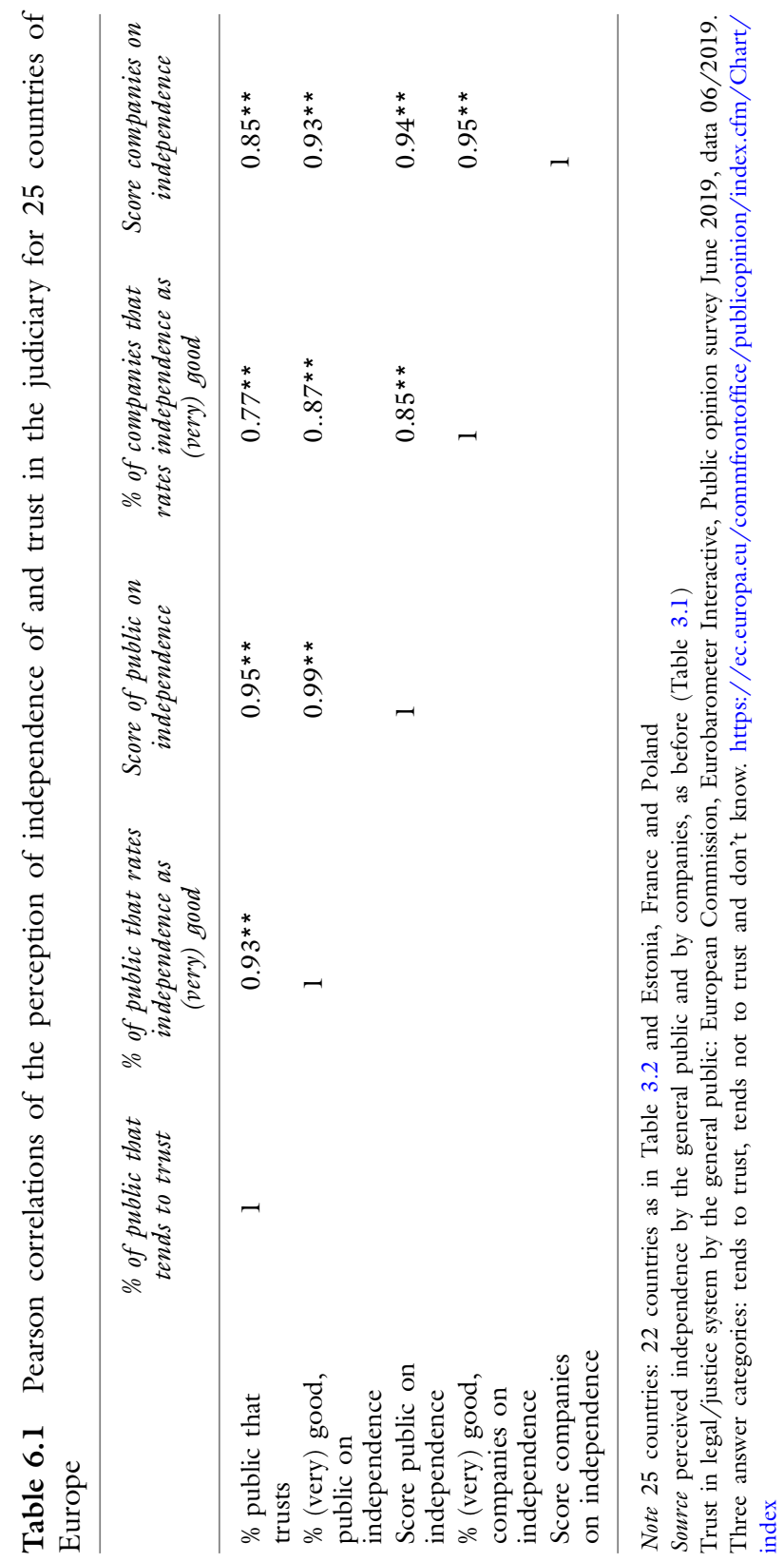




\subsection{Trust in National Institutions}

Trust in the three powers of the state differs widely among the countries of the EU (see also Sapignoli 2018). According to the public opinion surveys of the EC, trust varies from Croatia, where an extremely low percentage of $17 \%$ of the respondents tends to trust the judiciary and an even lower $13 \%$ both of the other state powers, to Finland, where $86 \%$ tends to trust the judiciary, $64 \%$ parliament and $56 \%$ the government. Not surprisingly, the outcomes for the three powers of the state are correlated. Still, substantial differences exist. Table 6.2 provides the summary data. The surveys show that in the mean trust in the national judiciary is higher than in the national parliament and the national government. According to the opinion surveys of the EC, higher trust in the judiciary than in parliament and government is found in most countries: in 16 out of the 25 EU-members that are included in this analysis. This is the case in all vested democracies, excluding Portugal and including Greece, while in Central Europe the Czech republic, Romania and Estonia exhibit this pattern. The gap between trust in the judiciary and that in the other powers of the state is often large in these countries, with the UK having an extreme gap of $38 \%$-point. The decision making process on Brexit has reduced trust in both government and parliament, and only the judiciary is left standing. In most (12) of these 16 countries parliament and government are trusted to the same extent. However, in Scandinavia trust in Parliament is higher than in government. The reverse is seen only in the Czech republic. Apparently, in vested democracies trust is not evenly distributed among the state powers. This pattern is found in national surveys as well. For example for the Netherlands where each quarter trust in a range of institutions is measured (Dekker and Den Ridder 2020), and in Germany (Vaterrodt et al. 2018).

In contrast to the main pattern, in many countries of Central Europe and also in Portugal, in total 8 countries, the trust in the judiciary is equal to the trust in both other state powers ( 4 countries) or equal to the trust in one of them and higher than that in the other (four countries). A situation where trust in the judiciary falls below trust in the other state powers is only and only weakly found in Slovenia where $26 \%$ tends to trust the judiciary, 31\% Parliament and 35\% government. Based on older data, Grönlund and Setälä (2012) finds similarly that trust in the legal system is larger than in parliament, except for Spain and Slovenia, based on the European Social Survey. Considering the two groups of countries 


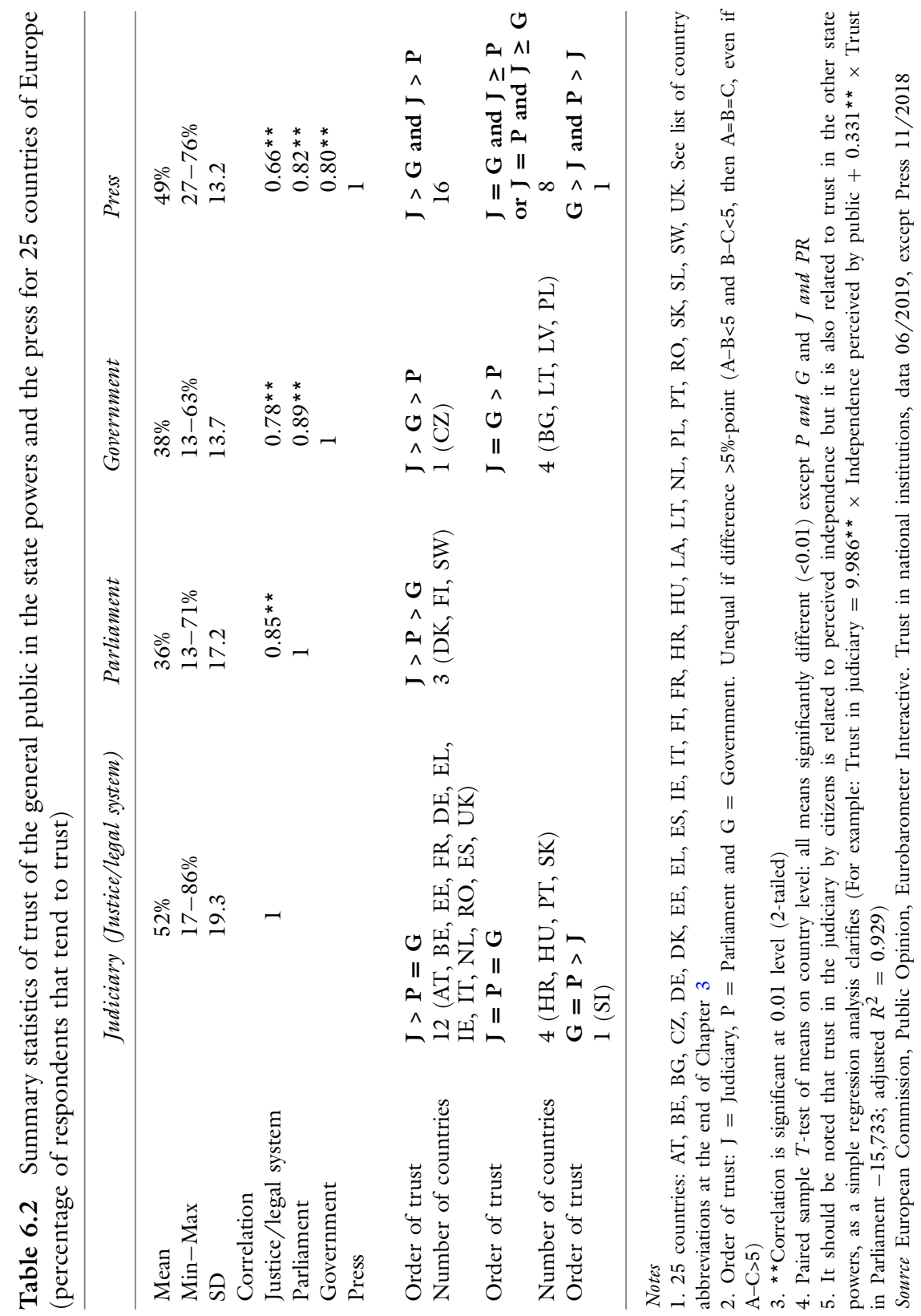


together, it is quite obvious that the pattern of relatively high trust in the judiciary generally goes together with a relatively high level of trust in the other two institutions.

As noted before, in a democracy the press plays a vital role in reporting about the functioning of the branches of government which is not directly observable by the general public, but the media can also be under the influence of the government or parliament, directly or indirectly. Media under the influence of the judiciary have not been observed yet. On average $50 \%$ of the respondents tend to trust the judiciary. The same percentage is found for the press. The cross country variation of trust in the judiciary is somewhat larger than of trust in the press. Higher trust in the judiciary than in the press or equal trust is predominantly found in established democracies with Belgium, Italy and Portugal as exceptions. This is neither good nor bad, except when differences are extreme. Extreme more trust in the judiciary than in the press is found for the UK (difference of 29\%-point), Ireland (17\%), Denmark (22\%) and Greece (26\%). The reverse is found for Croatia (24\%), Slovakia (18\%) and Portugal (17\%). These outcomes lead to interesting questions about the impact of reporting in the press on trust. It could well be that negative reporting ("enemies of the people") reduces the trust in the judiciary, but even more the trust in the press itself.

To check whether this pattern is specific for Europe, a comparison can be made with the United States where confidence of the general public in public institutions is measured as well. In 2019 the confidence in the judiciary stood at $69 \%$ for the US Supreme Court, 65\% for the State Court system and $65 \%$ for the Federal court system (percentage of the respondents that answer that they have a great deal or some confidence; GBAO 2020). These levels of trust are higher than the European mean, and are comparable with the figure for Germany. Only in Scandinavia and the Netherlands trust in het judiciary is higher than the mean for the US. The comparison at the state level is most relevant here. Confidence in the State Courts $(65 \%)$ is higher than in the State Legislature (58\%) and Governor (59\%). The differences are, however, smaller than in the EU. Thus, the same phenomenon is observed in the US, but in less extreme form than in the EU. It should be noted that in the US while the confidence in the judiciary increased since the start of the current surveys eight years ago until 2018, it sharply declined in 2019 (from 76 to 65\%). The same happened to the other branches of government, but the decline hit the courts harder (Governor from 60 to $59 \%$ and State legislature from 65 to $58 \%)$. 
Switching to the development over time over a longer period, since 2004, the first year when most current EU members participated in the survey, trust in the judiciary has increased on average with $20 \%$. In contrast, trust in parliament declined with 6\%, and in government it increased a little with $3 \%$. Trust in the press increased over the whole period with 9\%. Developments within the EU have been uneven. Departing from the average are in particular, negatively, Greece (judiciary: $-13 \%$ decline, parliament: $-36 \%$, Government: $-31 \%$ ), Croatia $(-7 \%,-12 \%,-13 \%)$, Spain $(-2 \%,-24 \%,-26 \%)$, Romania $(+13 \%,-10 \%,-19 \%)$, UK $(+7 \%,-18 \%,-13 \%)$ and France $(+13 \%,-$ $11 \%,-2 \%)$, and positively: the Netherlands $(+22 \%,+15 \%,+25 \%)$, Poland $(+21 \%,+24 \%,+25 \%)$ and Sweden $(+19 \%,+15 \%,+17 \%)$. These patterns are largely unsurprising, as they reflect the impact of the banking and sovereign debt crises that worked out differently across countries, and specific events such as Brexit. The results for Poland are intriguing, as they do not presage the current backsliding. Poland was one of the frontrunners in the accession to the EU and thereby in reforming its government/governance structure (Coman 2014).

These outcomes could easily lead to the conclusion that of the three branches of the state the judiciary is trusted the most. However, matters are more complicated. The public opinion surveys of the Eurobarometer also ask the public whether they tend to trust the public administration and the regional and local authorities in their country. Also trust in the police is regularly surveyed. See Table 6.3.

Average percentages of those who tend to trust institutions across countries are much the same for the judiciary, public administration and regional and local public authorities. In only seven countries the trust in the legal system is substantially higher than in both other public sector institutions. This group is dominated by North Western European countries. In all other countries trust is equal and more often lower than in the other institutions. The trust in the police $(70 \%$ on average) is much higher than in the judiciary. ${ }^{1}$ Only in Austria police and judiciary rank the same.

The conclusion is that the trust in the judiciary differs from trust in government and parliament but not from the trust in, what is called, the public administration and regional and local public authorities. It

\footnotetext{
${ }^{1}$ In the US confidence in the local police is expressed by $77 \%$ of the respondents in 2019 , down from $89 \%$ in 2018 . The difference in 2019 between state judiciary and police is smaller than in the $\mathrm{EU}$ ( 12 vs $18 \%$-point).
} 


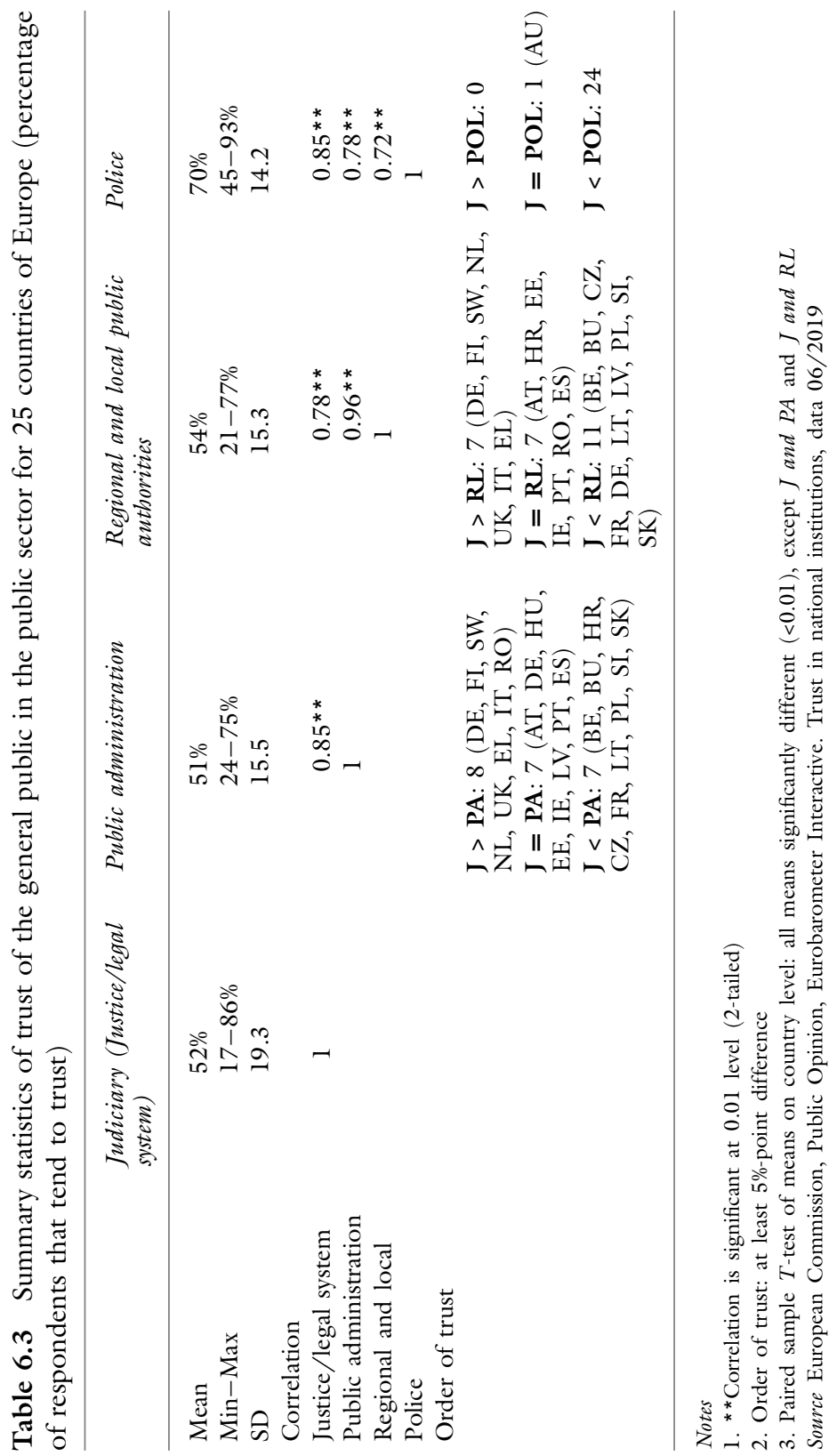


is not self-evident how the respondents interpret "the government" and "the public administration". It seems likely that public administration is primarily seen as the implementer of public policies and the provider of public services. This reflects the classic distinction between policy development and policy implementation: the first is political, and the second should ideally be a political and impartial, being subject to judicial review. This separation from politics is made explicit for autonomous agencies and in particular for regulators that, largely stemming from EU-law, are fully independent from national political institutions, and whose independence is protected by the judiciary. Grönlund and Setälä (2012) make a distinction between representative institutions and institutions primarily responsible for implementing laws (in particular the judiciary), and argue that representative institutions require a certain level of distrust (see also Warren 1999).

If correct, the public administration is less political than the government, and has the potential to be more trustworthy for a broader spectrum of the population than the political institutions of government and parliament. Although less clear-cut, the same reasoning could apply to regional and local public authorities that provide local services. Given the strong connection between independence and trust with regard to the judiciary, it is conceivable that related concepts such as fairness and impartiality play a role in the minds of the respondents with respect to the other institutions. Of course, the independence of the judiciary is fundamental and guaranteed by formal safeguards, while the position of the public administration is ambivalent (Papadopoulos 2013). Still, the same values as to the application of rules may be shared: whatever the rules, people need to be treated equally. However, the reasoning can also work the other way around. The fact that the extent to which the judiciary is trusted does not differ much from the trust in the public administration, can also be caused by the judiciary not being as independent as it should be. A further consideration is that in a national context the judiciary may be part of a legal/judicial system that is not supported by all political parties, and, consequently, it is drawn into the political field.

To summarize, the nature of the mission of the judiciary, including the impartial interpretation of the law and protection of rights, can be expected to (but need not always) foster trust more easily than the political system can or even should. A normative conclusion that the judiciary functions "better" than political institutions is not warranted. The judiciary is more akin to public administration than to political institutions, and a comparison with the public administration is more informative. 


\subsubsection{Trust, Knowledge and Politicization}

Citizens can and do distinguish the judiciary from political institutions (the government, the parliament), but does the general public see a difference between the judiciary and other public institutions? Are the institutions the same in terms of trust, as suggested above, or are citizens not aware of the differences? The rule of law survey of the EC that is discussed in Chapter 3 shows that knowledge about the judiciary does not go deep. At best, citizens have a general understanding of what the judiciary is about. As a result, people who do not have direct or indirect experience with the courts, fall back on their institutional trust in (the non-political part of) the public sector in general or even their dispositional trust (see Chapter 2). This lack of specific understanding about the judiciary could also (partly) explain why citizens who are lay judges have a very different, much more positive perception of judicial independence than citizens in general (Chapter 4).

The awareness of the public of the specific role and position of the judiciary is likely to be time and location dependent. In stable times citizens may be only superficially aware of the judiciary and its independence. It is, however, difficult to imagine that in Poland the struggle between judiciary and government has gone unnoticed to the general public. In Poland trust in the judiciary is roughly at the same level as trust in government and parliament, and much lower than in the public administration and the regional and local public authorities (37\% versus $47 \%$ and $56 \%$ in June 2019). The politicization of the position of the judiciary in Poland shows in these figures. If we extend the reasoning that the position of the judiciary is likely to be politicized if trust in the judiciary falls short of the trust in the public administration and the regional and local public authorities, more countries are in this situation. For instance, Bulgaria, Slovakia, Slovenia and Lithuania, but also Belgium display this pattern to the same extent as Poland.

\subsection{Trust in Multi-Level Governance}

The combination of the surveys about national institutions and EU institutions makes it possible to examine multi-level governance by comparing trust in the supranational institutions with trust in the institutions at the national level (see Arnold et al. 2012). In addition, the differences between the trust in the same European institutions, in particular the 
European Court of Justice, by the citizens of the different member states can be examined, and related to trust at the national level. Table 6.4 shows that on average across countries the differences in trust between the state powers at the EU level are much smaller than at the national level. The European Court of Justice and the European Commission are actually indistinguishable trustwise, while the European Parliament stands apart from the European Court of Justice. As above, this raises the question whether respondents can differentiate between the EU institutions in the way they do nationally. According to another component of the public opinion surveys of the EC, ${ }^{2}$ most people are aware of the existence of the European Parliament (93\%), the European Commission (85\%) and the European Court of Justice (71\%), while people are much less aware of other EU institutions such as the European Ombudsman (41\%) and the Economic and Social Committee (40\%). The European Central Bank is well known as well (82\%). Being aware is one thing, being able to differentiate between the performance of the institutions is another, but also the more technocratic nature of the EC than the political institutions at the national level may have an impact. If the EC is seen more as a public administration than national governments are, trust in the EC would be higher than in national governments for this reason alone. Table 6.4 shows also that the spread of outcomes for the national institutions among countries is much larger than for the corresponding EU institutions. This is not surprising as the same EU institutions are evaluated by the respondents, but of course in different ways across countries, while the national institutions differ as such.

On average across countries the trust in the justice system at the EU level is the same as at the national level, while the trust in the other state powers is much lower nationally than at the EU level. This fits in with the notion that the national courts and the ECJ and by extension the ECHR form one judicial system with the rule of law at its core ("national judges are European judges"). ${ }^{3}$ Its level of integration is higher than that of the national governments and the EC as well as the national parliaments and the EP.

${ }^{2}$ EC (2019). Public opinion, Awareness of the EU institutions. Data November 2019. https://ec.europa.eu/commfrontoffice/publicopinion/index.cfm/Chart/index.

${ }^{3}$ E.g. Frans Timmermans, Vice President of the EC, on Twitter 21 February 2019. 


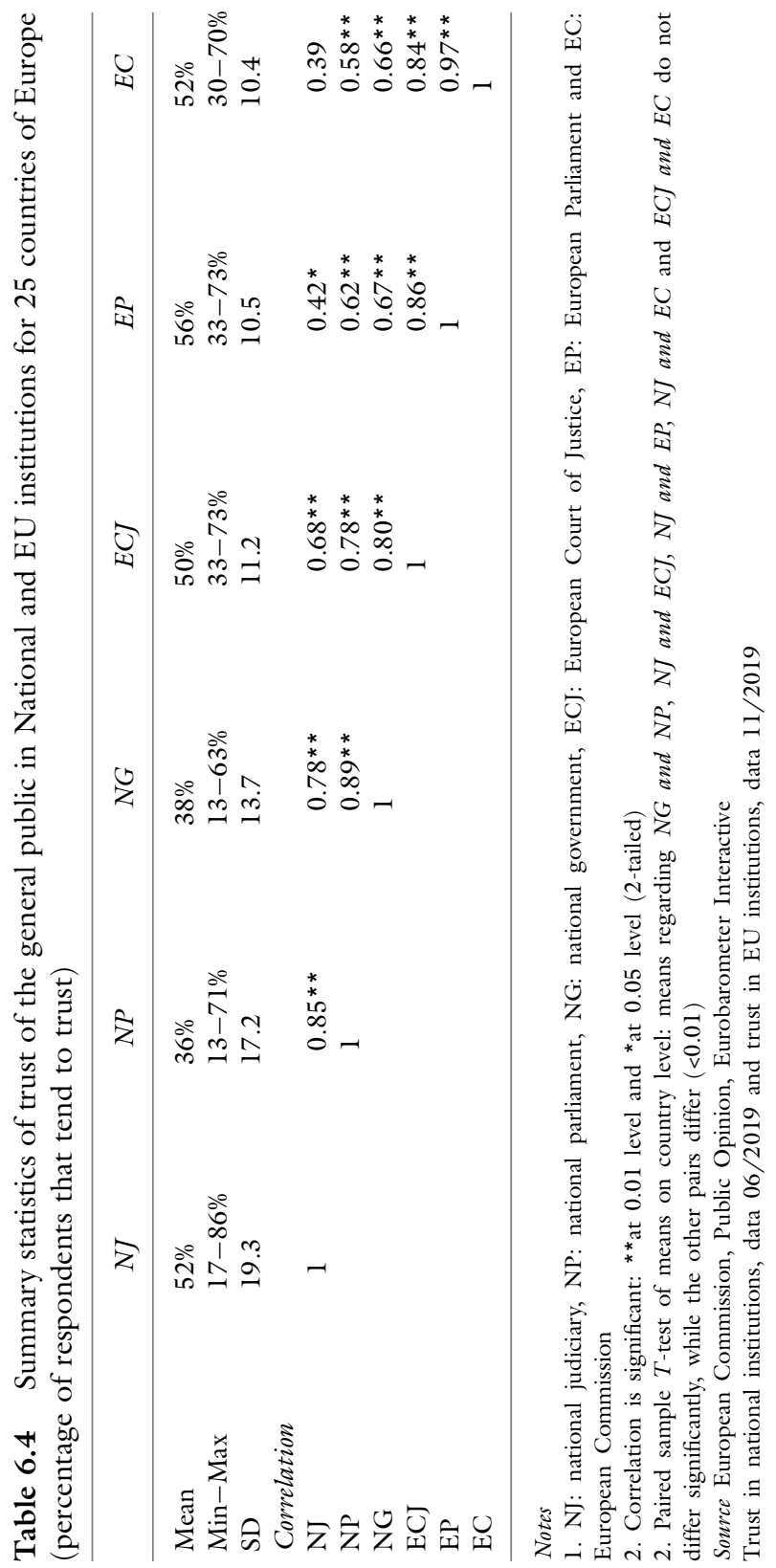


At the country level, high trust nationally combines with a lower level of trust in the ECJ, and low trust nationally combines with higher trust in the ECJ (see Fig. 6.1a). Still, countries with high trust nationally, have more confidence in the ECJ than countries with low trust nationally. To illustrate: if trust in national justice is smaller than $50 \%$, then the trust in the ECJ is higher than trust in national justice in 9 out of 12 countries, in 2 equal and only in one country substantially lower (Czechia). If trust is higher than $50 \%$, in 12 out of 13 countries trust in the ECJ is lower than in the national courts (Belgium is the exception). Trust in the ECJ is higher in these countries than in the countries that have low trust in their judiciaries ( $57 \%$ tends to trust the ECJ vs $44 \%$ ).

In Fig. 6.1 the trust in the three state powers is mapped for the national and the EU level. The logical consequence of the outcomes on trust discussed so far is that only for the judiciary there is a tipping point (at $50 \%$ ), where higher trust in the ECJ turns into lower trust than nationally. For the other branches of government trust in the national institutions is nearly always lower than or equal to the trust in the EU institutions. These data are intriguing. National judiciaries command more trust than the other state powers in their political manifestations. As we saw in the previous section, this may have to do with the non-politicized nature of their judicial tasks that allows broad trust to develop among the population, but also with being embedded in an EU judicial system that from the top of the ECJ and the ECHR tries to promote and protect the independence and quality of the national judiciaries. This follows from their judgments but also from their (moral) leadership role in Europe.

Whether the trust of the population of a country in the ECJ is helpful in protecting judicial independence in countries with judiciaries that are under pressure from government and parliament, is an open question. In several of these countries the percentage of citizens that trust the ECJ falls below $50 \%$, and that level of support may not sway government and parliament to implement unwelcome decisions of the ECJ. Nonetheless, the ECJ is likely to have a stabilizing influence on national judicial systems.

\subsection{Trust And Respect of Independence}

In this chapter the very high correlation of independence as perceived by citizens and their trust in the judiciary was discussed. In Chapter 3 the correlation between independence as perceived by judges and by citizens was examined. The connection between these concepts and respect 

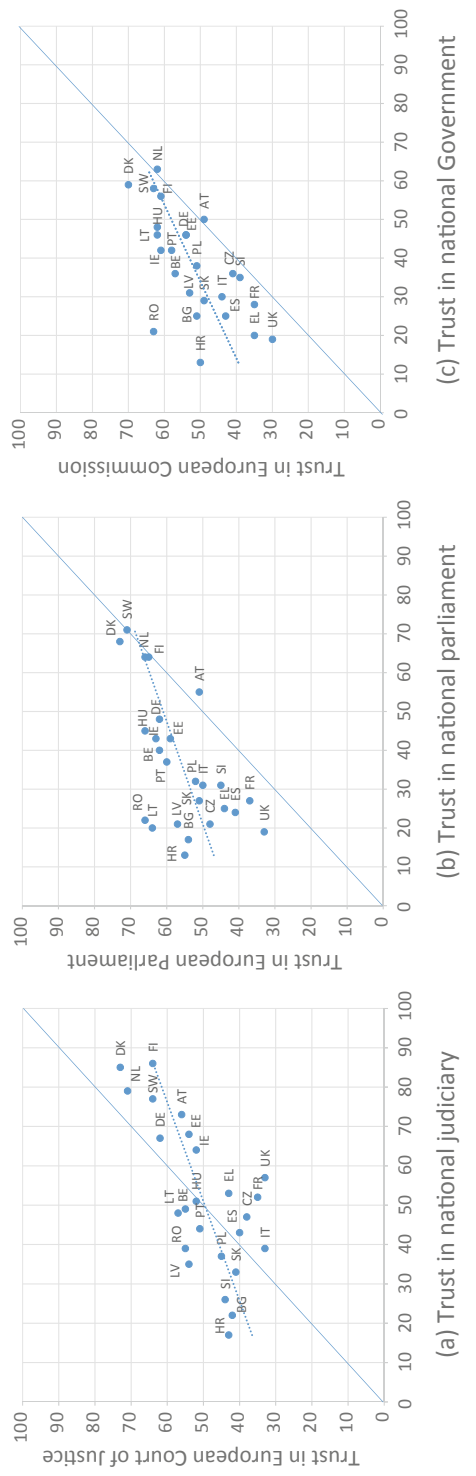

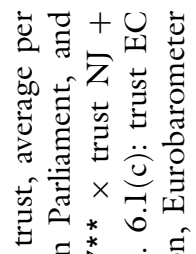

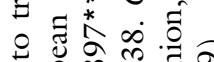

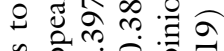

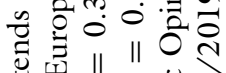

두의

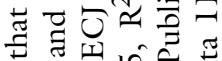

๑

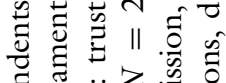

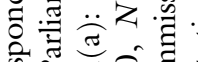

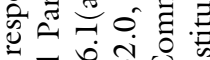

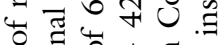

$\circ \circlearrowright 0+\Xi$

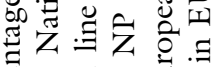

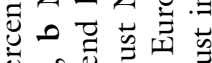

ปิ巳寸

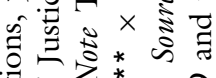

岂乙次的

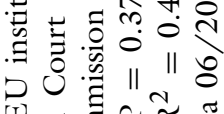

工 छ

Ð0ั

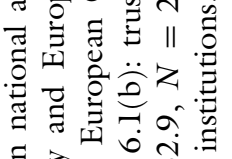

:

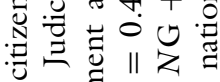

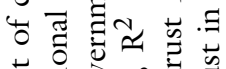

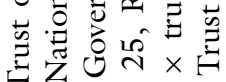

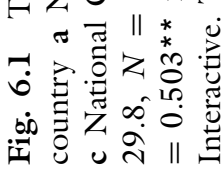


for independence was not yet discussed. Table 6.5 gives the correlation between respect for independence by the main actors on the one hand and perceived independence and trust on the other hand.

While all correlations between variables at the national level are significant, respect for independence from parties and lawyers is particularly connected with judicial independence and trust. As such, this does not tell us anything about causality. However, respect for independence is based on the perceptions of judges, and it is likely that causality runs directly from their experience of respect for independence to their perceptions of independence. As to the connection between respect perceived by judges and perceived independence by citizens and their trust in the judiciary, causality is likely to run both ways. Parties, in particular, will be more respectful for judges, the more they are convinced of their independence and the more they trust them. At the same time, respect enhances independence and thereby trust.

Respect for independence by parliament and government is less strongly correlated with the perceptions of independence and trust, with the media taking a position in the middle. Respect and legitimacy of judges in the political field are less directly associated with the daily work of judges in their court rooms. Respect for independence by the other state powers has to do with matters of demarcation of responsibilities and resource allocation, as discussed in Chapter 5 . The correlation of the

Table 6.5 Pearson correlations between independence and respect for independence as perceived by judges and independence and trust perceived by citizens

\begin{tabular}{llcccc}
\hline & & Judges on & Citizens on & \\
\cline { 3 - 5 } & & Independence & Independence & $\begin{array}{c}\text { Trust in } \\
\text { Judiciary }\end{array}$ & Trust in ECJ \\
\hline \multirow{3}{*}{$\begin{array}{l}\text { Respect for } \\
\text { independence }\end{array}$} & Larties & $0.82^{* *}$ & $0.79^{* *}$ & $0.86^{* *}$ & $0.60^{* *}$ \\
by: & Parliament & $0.88^{* *}$ & $0.81^{* *}$ & $0.84^{* *}$ & $0.46^{*}$ \\
& Government & $0.59^{* *}$ & $0.60^{* *}$ & $0.66^{* *}$ & 0.41 \\
& Trad. media & $0.72^{* *}$ & $0.53^{*}$ & $0.59^{* *}$ & 0.40 \\
& & & $0.71^{* *}$ & $0.76^{* *}$ & $0.58^{* *}$ \\
\hline
\end{tabular}

Notes

1. 22 countries

2. All variables are scores between $0-10$, except trust in judiciary and ECJ which are \% of respondents that tend to trust. 
trust in the ECJ and the respect shown by the court users emphasizes the connectivity of the EU legal system.

\section{REFERENCES}

Arnold, C., E.V. Sapir, and G. Zapryanova. 2012. Trust in the institutions of the European Union: A cross country examination. European Integration Online Papers, Special Mini-Issue 2: 16.

Coman, R. 2014. Quo vadis judicial reform? The quest for judicial independence in Central and Eastern Europe. Europe-Asia Studies 66 (6): 892-924.

Dekker, P., and J. den Ridder. 2020. Burgerperspectieven 2020/1. SCP.

GBAO. 2020. State of the State Courts, Survey analysis.

Grönlund, K., and M. Setälä. 2012. In honest officials we trust: Institutional confidence in Europe. American Review of Public Administration 42 (5): 523-542.

Papadopoulos, Y. 2013. Democracy in crisis? Politics, Governance and Policy. Cham: Palgrave Macmillan.

Sapignoli, M. (2018). Trust in justice in EU countries: Level of support and correlated factors. Paper prepared for 2018 EGPA Conference, Study Group XVIII on Justice and Court Administration.

Vaterrodt, J., M. Bohlen, and M. Sommer. 2018. Einstellung der Bevölkerung zum deutschen Justizsystem und zur Außergerichlichten Konfliktlösung; Roland Rechtsreport 2019, IfD Allensbach and Roland.

Warren, M.E. 1999. Democratic theory and trust. In Democracy \& trust, ed. M.E. Warren, 1-21. Cambridge: Cambridge University Press.

Open Access This chapter is licensed under the terms of the Creative Commons Attribution 4.0 International License (http://creativecommons.org/licenses/ by $/ 4.0 /)$, which permits use, sharing, adaptation, distribution and reproduction in any medium or format, as long as you give appropriate credit to the original author(s) and the source, provide a link to the Creative Commons license and indicate if changes were made.

The images or other third party material in this chapter are included in the chapter's Creative Commons license, unless indicated otherwise in a credit line to the material. If material is not included in the chapter's Creative Commons license and your intended use is not permitted by statutory regulation or exceeds the permitted use, you will need to obtain permission directly from the copyright holder.

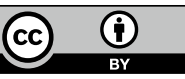

